\title{
The Future of International Law is Cognitive- International Law, Cognitive Sociology and Cognitive Pragmatics
}

\author{
Benedikt Pirker and Jennifer Smolka*
}

(Received 20 April 2018; accepted 4 July 2018)

\begin{abstract}
Scholars today discuss international law from various methodological angles. This Article aims to add perspectives from cognitive science, namely cognitive sociology and cognitive linguistics, or, to be more precise, cognitive pragmatics. It briefly elaborates on these fields' respective approaches, benefits, and limits. To clearly delineate the usefulness of the methodologies, this Article separately applies both approaches to the same example of a process of interpretation in international law. This Article concludes that the two cognitive approaches can help lawyers better understand and implement international law. This not only provides a description of the process of interpretation, but will hopefully enable a better practice of international law.
\end{abstract}

Keywords: International law; cognitive science; sociology of international law; international law and language; linguistics; pragmatics; cognitive sociology; cognitive linguistics; cognitive pragmatics; Relevance Theory

\section{A. Introduction}

Today, scholars examine international law from a number of methodological and disciplinary angles. This Article proposes a new way of looking at the topic. Cognitive science has not yet fully emerged as a methodology for examining the operation of international law. ${ }^{1}$ It can, however, contribute significantly to our understanding of the processes of international law. To make this argument, this Article selects two approaches, cognitive sociology and cognitive linguistics, or, to be more precise, cognitive pragmatics. Approaches to international law based on non-cognitive sociology and linguistics already exist. These have already proven their worth for studying international law. This Article will demonstrate the added contribution of a cognitive approach.

This Article first presents one central example of a process of interpretation in international law. The interpretation's application of legal methods and its outcome have been met with criticism from a doctrinal angle. This Article shows that by adopting cognitive methods, one can discover and examine additional aspects of this particular process of interpretation. As in most cases of applying a different methodology to international law, the aim is not to displace or replace

\footnotetext{
${ }^{*}$ Benedikt Pirker is Senior Lecturer at the Institute for European Law, University of Fribourg, benedikt.pirker@unifr.ch. Jennifer Smolka is linguist and translator at the Swiss canton of Valais, jennifer.smolka@admin.vs.ch. The authors thank the participants of the 2017 Workshop on Cognitive Sociology, Culture and International Law at iCourts, University of Copenhagen, Prof. Moshe Hirsch, Dr. Ziv Bohrer, Raffael Gnädinger, Marie Fonjallaz, Rowan Siegenthaler and the anonymous reviewers and the editorial team of the German Law Journal for helpful comments on earlier versions of this paper. The research leading to this article has received funding from the Jean Nordmann Foundation. The usual disclaimers apply.

${ }^{1}$ The small number of emerging approaches will, however, be addressed where appropriate throughout the Article. re-use, distribution, and reproduction in any medium, provided the original work is properly cited.
} 
the actual practice or doctrines of international law. Rather, it is to provide a better understanding of how international law actually operates in reality, so that-ideally-international lawyers may be better equipped to practice international law.

\section{B. An Example: Prisoners of the Sea}

In a well-known treatise on treaty practice and interpretation in international law, Aust describes what he considers to be an example of good interpretation. ${ }^{2}$ As we will discuss this central example in detail and continue to rely on it throughout the Article, it is useful to provide a lengthy excerpt from Aust's book:

\section{Implied terms}

Although it is not for an international tribunal to revise a treaty by reading into it provisions that it does not contain, except by necessary implication, it is sometimes necessary to imply a term, and this has been the approach of the International Court of Justice (though it will not 'revise' a treaty on the pretext that it has found an omission) and the European Court of Human Rights which does so. Here is an example that, like most cases of interpretation, did not end up in court. At the end of the Falklands conflict in 1982 there was not enough accommodation in the territory for the approximately 10,000 Argentine prisoners of war (POWs) captured on land in the final stages, the tents intended for them having been lost at sea when the ship carrying them was sunk by enemy action. Following consultations by the United Kingdom with the International Committee of the Red Cross, it was decided that the POWs could be kept on merchant ships and warships in Falklands waters until they could be repatriated. Article 22 of the Third Geneva Convention clearly prohibits holding on ships POWs who are captured on land, but given that the primary object and purpose of that Convention is the welfare of POWs, one could properly imply a term to the effect that when, for reasons beyond its control, a party to a conflict is unable to comply with Article 22, it may hold POWs on ships if that is preferable to leaving them on land without sufficient protection from the elements. Good interpretation is often no more than the application of common sense. ${ }^{3}$

Under a classic doctrinal approach, we would at this point look at the mentioned legal provision, Article 22 of the Third Geneva Convention. This prescribes the following:

Prisoners of war may be interned only in premises located on land and affording every guarantee of hygiene and healthfulness. Except in particular cases which are justified by the interest of the prisoners themselves, they shall not be interned in penitentiaries. Prisoners of war interned in unhealthy areas, or where the climate is injurious for them, shall be removed as soon as possible to a more favourable climate.

The Detaining Power shall assemble prisoners of war in camps or camp compounds according to their nationality, language and customs, provided that such prisoners shall not be separated from prisoners of war belonging to the armed forces with which they were serving at the time of their capture, except with their consent.

It does not seem difficult to put forth a doctrine-based criticism of Aust's proposed interpretation. Although an international law expert rather than an international court is interpreting the relevant norm here, the usual rules of interpretation arguably still apply. Without examining them at

\footnotetext{
${ }^{2}$ Anthony Aust, Modern Treaty Law and Practice 221-22 (2013).

${ }^{3}$ Aust, supra note 2.
} 
length, these customary rules are essentially enshrined in Articles 31 and 32 of the Vienna Convention on the Law of Treaties. ${ }^{4}$ Put very succinctly, they prescribe that one should take into account a treaty's text—-the ordinary meaning of a treaty's terms-, context, object, and purpose. ${ }^{5}$ Of course, we are leaving many nuances aside at this point. For our purposes, however, it is sufficient to note that we can distinguish two points of view with regard to the ordinary meaning of terms. Some-notably Aust himself-consider that a textual or literal approach requires interpreters to only look at the object and purpose of a treaty to confirm what they have already found when examining the text and context of a treaty norm. ${ }^{6}$ A competing view suggests that all of these elements are to be taken in conjunction for the purposes of interpretation; the ordinary meaning is not to be taken separately, but constitutes only a "very fleeting starting point."7 It is not difficult to see that Aust's pragmatic approach of reading an implied term into a treaty ("... one could probably imply a term ...") conflicts with the view that the treaty text is of primary importance.

The treaty text states POWs captured on land are to be held on land, and ships-where they are held in our example-are not on land, at least according to a cursory glance at the provision. A contrasting assessment would point out that the context, object, and purpose of the treaty provide elements that bolster Aust's proposed interpretation. For example, the protection of POWs from unhygienic or adverse climatic conditions that Article 22 seems to imply as an important goal. While it is interesting as a matter of principle, this is about as far as a doctrinal analysis of-or controversy around-the example goes.

That being said, the question arises as to how we can learn more from this-or otherexamples. Aust's proposal would arguably strike some readers as rather daring, mostly because of the brevity with which he explains the solution, and the confidence with which he defends it as a common sense interpretation in international law. It is an ideal example to better understand the operation of international law because it lends itself to looking at international lawyers themselves, in this case the operation of their minds. As the subsequent sections aim to show, a cognitive approach can help us better understand international law as a phenomenon and as a cognitive practice.

\section{From the Sociology of International Law to the Cognitive Sociology of International Law}

Sociology provides one cognitive method of examining international law. There is already a multitude of writing on the sociology of international law. Sociology itself has taken a cognitive turn, however, that international law has not yet fully embraced. By looking again at our example, we can highlight the use of a cognitive sociological approach to international law.

\section{Sociology of International Law}

The sociology of law in and of itself is best understood as a way of studying the phenomenon of law in a different way from legal dogmatics. Legal dogmatics typically sees the legal system as autonomous and composed exclusively of rules that are formally part of the law; it focuses on those rules, takes the perspective of a participant in a given legal system and engages in efforts of systematization and interpretation using methods internal to the legal system. ${ }^{8}$ By contrast, the sociology of law takes the perspective of an observer; it examines factual behavior, practices, and institutions, and also looks at informal sources of law as well as the law in its social context. It

\footnotetext{
${ }^{4}$ Vienna Convention on the Law of Treaties, Jan. 27, 1980, 1155 U.N.T.S. 331.

${ }^{5}$ Benedikt Pirker \& Jennifer SmolKa, Making Interpretation More Explicit: International Law and Pragmatics, 86 NoRDIC J. INT'L L. 226-29 (2017) (detailing this topic in more depth).

${ }^{6}$ See Aust, supra note 2, at 209.

${ }^{7}$ See Richard Gardiner, Treaty InTERPRETAtion 161-62 (2010).

${ }^{8}$ Kaijus ERVASti, Sociology of Law as a Multidisciplinary Field of Research, 53 ScANDINAVIAN StUd. IN L. 142 (2008).
} 
relies on the methods of the social sciences, for example empirical analyses, and aims to explain and critically examine social processes related to law. ${ }^{9}$

With regard to international law, different schools of sociological thought have developed since the early $20^{\text {th }}$ century. A central distinction can be drawn between the positivist and non-positivist approaches. A positivist approach maintains the distinction between law and non-law and purports to mainly describe international law. ${ }^{10}$ According to this view, the task of the sociology of law is to break down the elements influencing international society, politics, culture, economics, etc. The goal is to provide knowledge so that international lawyers can better exercise their professional role. ${ }^{11}$

Non-positivist approaches see the sociological approach to international law as a progressive enterprise. In this view, the sociology of law should not solely examine the current state of international law, but should also champion certain interests. For example, the idea that the interests of the international community ought to enjoy priority over those of the state in international law. ${ }^{12}$ The sociology of law is thus understood to serve ideological projects. ${ }^{13}$ Consequently, positivism and sociological approaches are in conflict. To give a recent example, in his work on the World Trade Organization, Cho suggests complementing the rationalist paradigm-which he sees as more prevalent in the past-with a constructivist approach to explain the functioning of the WTO community. ${ }^{14}$ Cho argues he is trying to make a difference for the future of the WTO through his work, and change the discourse on trade. ${ }^{15}$ This is not to suggest that such endeavors are per se problematic or must be rejected. Rather, this feature should be kept in mind as an important difference between the sociological approach and some of the other approaches discussed at a later stage.

Sociology is characterized by theoretical pluralism. Typically, in the sociology of international law a number of strands can be distinguished from each other. First, a structural-functional perspective is part of the tradition of macro-sociology. It focuses on large scale groups and patterns. Social patterns constitute external constraints imposed on individuals who, in turn, have limited opportunities to change these social facts. ${ }^{16}$ Second, a symbolic-interactionist perspective, by contrast, understands social structures as constituted and changed by the interactions of individuals. ${ }^{17}$ Third, a social conflict perspective focuses on social relations at the macro-level, but understands society as primarily characterized by patterns of inequality of resources alongside struggle and

\footnotetext{
${ }^{9} I d$. at 143 .

${ }^{10}$ Typically, Max Huber, Die soziologischen Grundlagen des VölKerrechts (1928), is mentioned as a representative of this approach. For more details on Huber's work, see generally JosT DelBRÜCK, Max Huber's Sociological Approach to International Law Revisited, 18 EUR. J. INT'L L. (2007).

${ }^{11}$ Anthony CARTy, Sociological Theories of International Law, in THE MAX Planck ENCyClopedia OF PUbliC INTERNATIONAL LAW 4-5 (Rüdiger Wolfrum ed., 2012).

${ }^{12}$ Georges Scelle, Précis de droit des gens: Principes et systématique, Part I (1932); Georges Scelle, Précis de DROIT DES GENS: PRINCIPES ET SYSTÉMATIQUe, PART II (1934). For a more comprehensive overview of the differences between Huber and Scelle, see Oliver Diggelmann, Anfänge der VölKerrechtssoziologie: Die VölKerrechtskonzeptionen von Max Huber und Georges Scelle im Vergleich (2000).

${ }^{13}$ Carty, supra note 11 , at 40.

${ }^{14}$ Sungjoon Cho, The Social Foundations of World Trade: Norms, Community, and Constitution 38-39 (2015); see Gregory Shaffer \& Joel P. Trachtman, Interpretation and Institutional Choice at the WTO, 52 VIRGINIA J. OF INT'L L. 103 (2011) (summarizing the rationalist paradigm).

${ }^{15}$ See CHO, supra note 14, at 238; see also Moshe Hirsch, The Sociology of International Investment Law, in THE Foundations of International InVEstment Law 146, 167 (Zachary Douglas et al. eds., 2014) (giving another example, in his examination of international investment law and its arbitration "community," Hirsch similarly suggests that applying the methods of sociology to international law may "occasionally bear implications for policy-making.").

${ }^{16}$ Also referred to as "systems theory;" see MosHE HiRSCH, The Sociology of International Economic Law: Sociological Analysis of the Regulation of Regional Agreements in the World Trading System, 19 EuR. J. INT'L L. 290 (2008) (referring to Emile Durkheim, Talcott Parsons, and Robert Merton as important representatives); see also Niklas Luhmann, A SOCIOLOGICAL Theory of Law (1985); see also Gunther Teubner, Autopoietic Law: A New Approach to LaW and Society (1988); Marc Amstutz, Global (Non)Law: The Perspective of Evolutionary Jurisprudence, 9 German L. J. 465 (2008).

${ }^{17}$ Moshe Hirsch, The Sociology of International Law, 55 U. ToronTo L. J. 902 (2005) (naming Max Weber, Herbert Blumer, and Harold Garfinkel as scholars following this approach).
} 
competition between rival groups. Dominant groups are thus interested in maintaining a status $q u o$, whereas disadvantaged groups aim to change the social order. ${ }^{18}$ In general, there is a notable openness to applying different theories, sometimes together. ${ }^{19}$

How could sociology be applied to international law in practice? Hirsch mentions treaty interpretation. He claims that in this context, a structural-functional perspective would lead actors to use a teleological approach first and foremost in order to identify a treaty's object and function in the international system, sometimes independently of the original intent of the authors. ${ }^{20}$ Under this approach, legal doctrines that emphasize flexibility in the implementation of a treaty regime would thus be met with skepticism. Take the margin of appreciation doctrine in the context of the European Convention on Human Rights, ${ }^{21}$ or, in the context of EU law, the clause of Article 4 (2) of the Treaty on European Union protecting the national identity of Member States, including their fundamental constitutional structures. In one recent case, the Court of Justice of the European Union approached Article 4 (2) with a structural-functional, pro-integrationist perspective: The Court had to decide whether a EU Member State was obliged to recognize a marriage between persons of the same sex concluded in another Member State in accordance with the law of that state for the purpose of granting a derived right of residence to a third-country national. The obligation could be based on the fundamental freedom of movement of persons enshrined in EU law. The Member State, by contrast, argued that it could justify a deviation from that freedom based on public policy interpreted together with Article 4 (2), that is the protection of its national identity including its fundamental constitutional structures. The Court, however, found that such a justification had to be interpreted restrictively and decided that there was an obligation to recognize same sex marriages in the mentioned circumstances. It thus gave no prominent role to the protection of Member States' national identity under Article 4 (2). ${ }^{22}$ One could argue that the Court took a pro-integrationist stance in line with a structural-functional perspective; a symbolic-interactionist perspective would have accorded greater weight to Member States and their national identity.

Thus, it is safe to conclude at this point that classic sociology is a tried and trusted approach to international law. By contrast, cognitive sociology appears to be much more of a desideratum.

\section{Cognitive Sociology}

Whereas cognitive sociology as a methodological approach to sociology goes back quite some time, it appears to have made its entry into the study of international law only recently. ${ }^{23}$ To understand cognitive sociology and its potential to contribute to the study of international law, we can look at its origins, its contribution, and some of its methods and concepts.

In the past, sociologists have tried to promote a turn towards cognitive science among their peers. ${ }^{24}$ It was, however, only towards the end of the $20^{\text {th }}$ century that new developments in cog-

\footnotetext{
${ }^{18} \mathrm{Hirsch}$, supra note 16, at 294 (referring to Karl Marx and Emmanuel Wallerstein as well-known representatives).

${ }^{19}$ Moshe Hirsch, Invitation to the Sociology of International LaW 159 (2015); see Moshe Hirsch, Explaining Compliance and Non-Compliance with ICSID Awards: The Argentine Case Study and a Multiple Theoretical Approach, 19 J. INT'L ECON. L. 683 (2016) (proving this point when, using international relations theories, he examines the same phenomenon in international law from different angles).

${ }^{20}$ Hirsch, supra note 17 , at 916 .

${ }^{21}$ William Schabas, The European Convention on Human Rights: A Commentary 78 (2015) (detailing and referencing to the jurisprudence).

${ }^{22}$ ECJ, 5 June 2018, Case C-673/16, Coman and Others, 42-45 (viewing the obligation of recognition did not undermine the institution of marriage, because the Member State did not have to provide in its own law for same sex marriages and the definition of marriage remained within the Member States' competence).

${ }^{23}$ Workshop on Cognitive Sociology, Culture, and International Law, University of Copenhagen (April 2017) http://jura.ku. $\mathrm{dk} /$ icourts/calendar/cognitive-sociology/. See in domestic law Luigi Cominelli, Cognition of The LAw: TOWARD A Cognitive Sociology of LaW ANd Behavior (2018).

${ }^{24}$ See Aaron Cicourel, Cognitive Sociology: Language and Meaning in Social Interaction (1974).
} 
nitive neuroscience enabled sociologists to argue that the related insights could help close the observability gap in sociology between the external and subjective aspects of culture. ${ }^{25}$

Cognitive sociology, in comparison to non-cognitive sociology, is thus about closing this observability gap or, in other words, opening the black box of socialization. ${ }^{26}$ More precisely, it aims to examine cognitive socialization. ${ }^{27}$ One scholar describes the added value as "making the link between the firing synapses.... and the organization of... sociocultural contexts in which ... processes occur." 28 Disciplines such as sociology look towards cognitive science because the latter provides an explanation of certain universal patterns of processes of the human mind such as thinking, reasoning, interpreting, understanding and decision-making. For example, research on decision-making shows that individuals generally seem to seek the highest cognitive task rewards for the lowest cognitive effort possible. ${ }^{29}$

As its main approach, cognitive sociology recognizes that humans share cognitive commonalities and that individual thinkers do not possess an exclusive uniqueness. ${ }^{30}$ It aims to identify the conventional. This term refers to the fact that cognitive sociology is not interested in and aims to steer clear of purely subjective factors. It does not, however, intend to convey the idea that all mindscapes are naturally or logically inevitable and thus objective; rather, it claims that they are created by thought communities such as professions or generations. ${ }^{31}$ Cognitive sociology thus focuses on the inter-subjective world distinct from both the subjective inner world of the individual and the objective physical outer world. ${ }^{32}$ It highlights the cognitive diversity humans possess as members of different thought communities, in contrast to the general tendency of cognitive science to emphasize the commonalities of the human mind..$^{33}$

Cognitive sociology has developed a comprehensive toolbox using the concepts generally employed in cognitive science. A well-known example is cognitive sociology's use of the distinction between processes of hot and cold cognition. Hot cognition is largely driven by emotion as a response to stimuli. Cold cognition designates painstaking thought and analysis. ${ }^{34}$ For example - using technology such as magnetic resonance imaging scanners-researchers are able to show that fear of natural dangers such as snakes activates the brain's emotional centers, whereas fear of more modern dangers such as guns activates decision-making areas. ${ }^{35}$ Evolution may be a suitable explanation for the hot cognition reaction to snakes. The cold cognition reaction to guns may arise from the need to analyze the social interactions in which modern dangers such as firearms arise. ${ }^{36}$ Cognitive frames used also by scholars in international law offer another enlightening example. ${ }^{37}$ In the process of communication, cognitive frames operate so that people choose pieces of information from a multitude of possibilities and then base other kinds of choices on the outcome of this pre-selection, often in

\footnotetext{
${ }^{25}$ Paul DiMaggio, Culture and Cognition, 23 Ann. Rev. Soc. 266 (1997).

${ }^{26}$ Laurence Kaufmann \& Fabrice Clément, L'esprit des sociétés. Bilan et perspectives en sociologie cognitive, in LA SOCIOLOGIE Cognitive 9 (Laurence Kaufmann \& Fabrice Clément eds., 2011).

${ }^{27}$ Eviatar Zerubavel, Social Mindscapes: An Invitation to Cognitive Sociology 15 (1997).

${ }^{28}$ Karen CERUlo, Mining the Intersections of Cognitive Sociology and Neuroscience, 38 PoETICS 119 (2010).

${ }^{29}$ Emilie M. Hafner-Burton et. al., The Cognitive Revolution and the Political Psychology of Elite Decision-Making, 11 Persp. on Pol. 372 (2013).

${ }^{30}$ ZERUBAVEL, supra note 27, at 2-3 (pointing to psychologists, linguists and scholars studying artificial intelligence who are all indifferent to the biographical background of their research subjects and thereby assume a universal human mind).

${ }^{31} I d$. at 9.

${ }^{32} I d$.

${ }^{33} I d$. at 10 .

${ }^{34}$ Cerulo, supra note 28, at 119.

${ }^{35}$ Arne OHMAn \& Susan Mineka, Fears, Phobias, and Preparedness: Toward an Evolved Module of Fear and Fear Learning, 108 PsYCHOL. REv. 483 (2001).

${ }^{36}$ Cerulo, supra note 28 , at 121.

${ }^{37}$ See Martin Wählisch, Cognitive Frames of Interpretation in International Law, in INTERPRETATION IN INT'L L. 338-39 (Andrea Bianchi et al. eds., 2015).
} 
the form of latent common assumptions. ${ }^{38}$ For example, for general observers and international lawyers, there is a great difference in the framing of a particular conflict as either a riot or a civil war. ${ }^{39}$

Let us look at an example of cognitive framing in the history of international law. In 1815, when news of Napoleon's escape from captivity became known to the representatives at the Vienna Congress, they signed a document, fearing that his return to Italy was imminent. In this written declaration, they pronounced Napoleon an outlaw, declaring in French that Napoleon had placed himself outside civil and social relations-"hors des relations civiles et sociales" - and, as an enemy and disturber of the tranquility of the world, had delivered himself to "la vindicte publique." The term vindicte is, however, open to two interpretations: It can mean public justice in the sense of prosecution or public vengeance. In the latter understanding, Napoleon would be an outlaw whom anyone could kill without punishment. Under English law, however, due process always required a trial before anyone could be outlawed, imprisoned, or executed. ${ }^{40}$ Wellington signed the document for Britain. Subsequently, his political opponents criticized him strongly for having sanctioned Napoleon's assassination without respect for the requirements of due process. ${ }^{41}$ Here cognitive frames offer a helpful explanatory tool. It seems as if the very framing of the issue as outlawry led Wellington's opponents to subsequently understand vindicte in the sense that Napoleon could be killed without trial. The declaration itself, however, was ambiguous. The criticism of Wellington was therefore based on this initial framing and the assumptions that his opponents derived from it, namely that due process had been violated by the mere fact of the declaration.

A final useful tool employed in cognitive sociology is graded membership. Conceptualization, or the building of concepts, works on the basis of prototypes or a best example premise. This means that concepts amplify the critical features of a category, focusing our brains on an ideal. When we subsequently encounter a token or referent of a given concept, the brain operates a process of graded membership, ranking entities with reference to others in their conceptual class. The more attributes an object-think, for example, of different tomatoes in the supermarket - shares with the prototype — think of the category of TOMATO — the more likely one will include it in the corresponding conceptual category and the closer it will be ranked to the ideal. ${ }^{42}$ It should be noted that there are also contrasting theories that cast doubt on some of the concepts and distinctions mentioned. ${ }^{43}$ Nonetheless, cognitive sociology offers a rich array of instruments to study international law.

\section{Towards a Cognitive Sociology of International Law}

As already indicated, there has not yet been any substantial writing on cognitive sociology and international law. ${ }^{44}$ Still, at this point, first reflections can be developed on how cognitive sociology

\footnotetext{
${ }^{38}$ See Luhmann, supra note 16 , at 31.

${ }^{39}$ Wählisch, supra note 37 , at 339.

${ }^{40}$ ANDrew Roberts, NAPOLEON AND Wellington 140 (2001).

${ }^{41}$ Gordon Corrigan, Wellington: A Military Life 284-85 (2001).

${ }^{42}$ See Cerulo, supra note 28, at 122; see also Karen Cerulo, Never Saw It Coming: Cultural Challenges to ENVISIONING THE WORST (2006) (describing the social implications of graded membership).

${ }^{43}$ See Hugo Mercier \& Dan Sperber, The Enigma of Reason (2017) (developing an interactionist theory of reason, drawing — as is often the case for theory development in cognitive science-from a broad range of disciplines. This theory casts doubt on the distinction between hot and cold cognition. In essence, it suggests that the observable shortcomings of reason are not a bug but an inherent feature with an evolutionary purpose. There is no maintainable distinction between better or worse or hot or cold aspects of cognition. Our system of producing reasons is much weaker than that of evaluating reasons. This, in turn, is explained by the fact that our system of reasoning is aimed at mutual discussion and evaluation of reasons rather than at solitary reflection).

${ }^{44}$ See Anne Van Aaken, Behavioral International Law and Economics, 55 HARV. INT'L L. J. (2014); see also Tomer Broude, Behavioral International Law, 163 U. PENN. L. REv. (2015) (drawing from cognitive science in the neighboring field of law and economics to develop behavioral international law and economics).
} 
could be employed in international law. If we return to our example of the prisoners held at sea, we find it comparatively easy to cast doubt on Aust's assessment that it was a good or common sense interpretation to claim that Article 22 of the Geneva Convention allowed the keeping of POWs on ships. Contrary legal arguments based on the text of the provision are readily available; after all, it prescribes that POWs ought to be held on land. How is it nonetheless possible for someone engaged in questions of humanitarian law to reach such a conclusion? Is it unreasonable? As noted above, Aust himself argues in favor of a textual or literal approach to interpretation. Is it a contradiction if he shortly afterwards proposes that sometimes there are implicit terms in treaties and that based on this holding POWs on ships is a permissible course of action under Article 22?

Arguably, cognitive sociology can help us explain the possible reasons for what happened. It does not offer an explanation at the doctrinal level; the criticism that the wording of Article 22 seems to contradict Aust's conclusion stands. In essence, our example seems to offer a choice between two evils: The British forces needed to decide whether to violate the obligation to hold POWs on land or the obligation to protect them from extreme weather conditions. ${ }^{45}$ Aust, however, goes beyond such a presentation. He recasts the whole example as a situation that does not entail any violation of Article 22 at all.

Perhaps the cognitive socialization of lawyers specialized in international humanitarian law can help to understand our example better. Arguably, based on their training and experience, such lawyers will form specific concepts and develop particular prototypes in their mind. Perhaps, what we observe in our example is a process of graded membership that may be somewhat more difficult to relive for others, even, to some extent, for other lawyers. Dealing with many cases of similar situations concerning the internment of POWs, humanitarian lawyers will develop a concept of what falls under the prototype or ideal of acceptable forms of internment and what does not. In our example, Aust may have gone through a process of graded membership. The prototype of acceptable forms of internment probably has a number of attributes, including a certain minimum level of protection from extreme weather conditions. Holding POWs on ships in the situation at hand may arguably have more in common with the prototype, and thus be ranked closer to it, than holding POWs on land where they are not at all sheltered from the rough weather of the Falkland Islands. In fact, holding POWs on land might have become in Aust's mind a means to an end, namely to provide an acceptable form of internment, rather than a separate legal criterion. Consequently, if understood through the lens of prototypical thinking and graded membership, Aust's reading of Article 22 and his conclusion that this constitutes a good and even reasonable interpretation makes much more sense. To confirm this thesis, one could even go on to examine whether humanitarian lawyers as a group would be more willing to agree with Aust's conclusion compared to other international lawyers. In summary, cognitive sociology helps us to think more deeply about examples like the one discussed.

At this point, however, many readers will notice that in terms of language we have offered no explanation as to how Aust can possibly conclude that on land can be interpreted as meaning on ships. This is no accident. Both sociology and cognitive sociology as applied to law do not focus on language itself and have a rather limited view of its operation.

\section{From (Cognitive) Sociology to (Cognitive) Linguistics: The Role of Language}

Sociology has quite an extensive literature focusing on law. Remarkably, however, there are few close examinations of interpretation and the role played by language. They seem to be taken as given facts to be explained by social factors. The focus lies instead on the interaction in the

\footnotetext{
${ }^{45} \mathrm{We}$ will deliberately leave aside another aspect worthy of discussion here, namely Aust's underlying assumption that the British forces were forced to act in this manner because of circumstances beyond their control. Of course, one could also raise the criticism that in a situation of war the British forces ought to have been prepared to lose part of their supplies, which would make the case of a simple violation of Article 22 stronger. But this is beside the point we are trying to make here.
} 
language used by interpreters - such as courts - and treaty drafters-such as states-in international law. ${ }^{46}$ Methods of interpretation are examined to determine whether they correspond to a given sociological approach. For instance, the teleological method looks for an overall function and purpose of a treaty in the system of international law. It is thus said to correspond to a structural-functional approach to international law. ${ }^{47}$ Language is not so much seen as a phenomenon to be examined, but as a ready-to-use instrument or code. WTO norms are accordingly called a "storehouse of historically accumulated collective meaning and experience" or a system of signs "comprised of typifications" that may turn a concrete social fact into a generalized, abstract pattern. ${ }^{48}$ The function of language is thus more of interest than language's functioning itself. The perception of language as a code is prevalent, but — as will be explained-cognitive linguistics casts significant doubt on this. Cognitive sociology agrees with Habermas ${ }^{49}$ that language is not merely used in an instrumental fashion to convey information, but as communicative and geared towards "action coordination and social integration". ${ }^{50}$ Like Wittgenstein, it sees language as necessarily public and a product of the cultural representation of a particular community, as discursive practices shaping narratives and a "collective representation of shared ideas and experiences". 51 Language thereby also constrains, as it cannot be fundamentally changed by individual parties, even in an inter se agreement. ${ }^{52}$

In cognitive sociology, a similar picture emerges. As far as we can see, language is viewed as allowing one to "convey [one's] thoughts to others" so that a "meeting of the minds" is possible. ${ }^{53}$ There has apparently been no further attempt to study in greater detail how such a meeting of the minds could function in practice. Often, language is also seen as inseparable from social practice because any such practice-be it economic, religious, scientific, or of another nature-is always organized and implemented through multiple linguistic practices. ${ }^{54}$ Based on this concept of language, cognitive sociology views sociolinguistics ${ }^{55}$ with skepticism as it looks for systematic relations between linguistic properties-pronunciation, style, etc.-and social properties-age, sex, social origin, etc. It allegedly oversimplifies the intersection between actors who speak and actors in their social context. ${ }^{56}$ According to cognitive sociology the existence of a limited number of ways of saying things - expressing rhetorical arguments and so on-is explained by the collective discursive socialization experienced by an individual. ${ }^{57}$ This theoretical explanation falls short of clarifying how we can reach definitive understandings if there is an innumerable quantity of social practices. Also, in light of the previously discussed fundamental cognitive universalities of human minds, the claim of a "clean slate" of language fully open to being defined by social practices does neither appear very likely nor convincing.

It seems, therefore, that both sociology and cognitive sociology leave the study of the actual operation of language to linguists. For our context of international law, the question asked by sociology and cognitive sociology seems to be merely what language can do in international law, but never how language can do all this in international law. Both sociology and cognitive

\footnotetext{
${ }^{46}$ Hirsch, supra note 17 , at 915 .

${ }^{47} I d$. at $915-16$.

${ }^{48} \mathrm{CHO}$, supra note 14 , at 121.

${ }^{49}$ JÜrgen Habermas, Between Facts and Norms: Contributions to a Discourse Theory of LaW and Democracy 18 (William Rehg trans., 1996).

${ }^{50} \mathrm{CHO}$, supra note 14 , at $121-22$.

${ }^{51} \mathrm{Id}$. at 124-25 (relying on Ludwig Wittgenstein, Philosophical Investigations 244 (G.E.M. Anscombe trans., 1953) (1967)).

${ }^{52} \mathrm{CHO}$, supra note 14 , at 125.

${ }^{53}$ Zerubavel, supra note 27 , at 8.

${ }^{54}$ Bernard Lahire, Les cadres sociaux de la cognition: socialisation, schèmes cognitifs et langage, in LA SOCIOLOGIE COGNITIVE 148 (Laurence Kaufmann \& Fabrice Clément eds., 2011).

${ }^{55}$ See William Labov, The Social Motivation of a Sound Change, 19 WORD 273 (1963).

${ }^{56}$ Erving GofFManN, Les Moments et LeUrs Hommes 146 (1988).

${ }^{57}$ Lahire, supra note 54, at 155.
} 
sociology assume that language is a ready-to-use code determined by social practice. This brings us to the next section, which will show that this view can be challenged by introducing cognitive aspects of linguistics.

\section{From Linguistics and International Law to Cognitive Pragmatics and International Law}

As we did with the case of sociology, we will first examine the relationship between linguistics and international law. We will then assess the cognitive turn that linguistics and, in particular its subfield pragmatics, has taken, and show how these disciplines may potentially benefit the study of international law. This is best demonstrated by returning to our initial example.

\section{Linguistics, Pragmatics, and International Law}

As far as we can see, there is no research cluster or body of literature in international law openly dedicated to linguistics. International law may deal, for example, with the linguistic rights of minorities ${ }^{58}$ or the role of different languages in international law. ${ }^{59}$ Linguistics itself has been used somewhat haphazardly at times rather than in a systematic effort to explore its potential. Notably, some international law scholars rely on something akin to discourse analysis. ${ }^{60}$ This contrasts with the broad interest linguists generally have developed for the law. While they tend to focus on domestic law, innumerable contributions deal with law from various linguistic angles. ${ }^{61}$ In light of this, we should at this point introduce some important directions of research in linguistics ${ }^{62}$ with regard to law. This introduction will make clear some crucial distinctions unfamiliar to international lawyers. ${ }^{63}$

A core distinction in linguistics is between semantics and pragmatics. Semantics is concerned with meaning as far as it is encoded in the formal components of a language; pragmatics looks at the way in which those components with such encoded meaning are used in particular contexts to communicate concepts or thoughts. ${ }^{64}$ One might be tempted to conclude that semantics and pragmatics represent two distinct models of how communication operates: A code model suggesting that communication is encoded, directly or indirectly, in language; and an inferential model whereby the communicator provides evidence of their intention to convey a meaning which is, in turn, inferred by the audience on the basis of the evidence provided as well as contextual information and the audience's knowledge. ${ }^{65}$ In practice, at least from a pragmatics perspective, which we will return to in the next section, the general understanding is that the two models

\footnotetext{
${ }^{58}$ Dagmar Richter, Language Rights Revisited: Rhe Challenge of Global Migration and Communication (2012).

${ }^{59}$ See Christian Tomuschat, The (Hegemonic?) Role of the English Language, 86 Nordic J. InT'L L. 196 (2017).

${ }^{60}$ See Fouad Zarbiev, A Genealogy of Textualism in Treaty Interpretation, in INTERPRETATION IN INTERNATIONAL LAW (Andrea Bianchi et al. eds., 2015); see also FouAd ZARBIEV, LE DISCOURS INTERPRÉTATIF EN DROIT INTERNATIONAL CONTEMPORAIN: UN ESSAI CRITIQUE (2015) (describing the approach as genealogical).

${ }^{61} \mathrm{See}$ The Pragmatic Turn in Law. Inference and Interpretation in Legal Discourse (Janet Giltrow \& Dieter Stein eds., 2017); see also ZUGÄNGe ZUR RechtsSEMANTIK: INTERDISZIPLINÄRE ANSÄtZE IM ZeitAlter DER MEDIATISIERUNG (Friedemann Vogel ed., 2015).

${ }^{62} \mathrm{We}$ leave aside, for our present purposes, law and literature approaches. See e.g. Andrea Bianchi, Terrorism and Armed Conflicts: Insights from a Law and Literature Perspective, 24 LEIDEN J. INT'L L. (2011); Ekaterina Yahyaoui Krivenk, International Law, Literature and Interdisciplinarity, 9 L. \& HUMAN. 9:1 (2015).

${ }^{63}$ See Jennifer Smolka \& Benedikt Pirker, International Law and Pragmatics: An Account of Interpretation in International Law, 5 INT'L J. LANGUAGE \& L. 16 (2016).

${ }^{64}$ Robyn Carston, Legal Texts and Canons of Construction: A View from Current Pragmatic Theory, in LAW \& LANGUAGE 9 (Michael Freeman \& Fiona Smith eds., 2013).

${ }^{65}$ See Deirdre Wilson \& Dan Sperber, Relevance Theory, in The Handbook of Pragmatics 607 (Laurence Horn \& Gregory Ward eds., 2006); see also SANDRINe ZufFerey \& JACQUes MOESCHLER, INITIATION À L'ÉTUde DU SENS 88 (2012).
} 
operate simultaneously and do not exclude each other; verbal comprehension includes decoding of linguistic information as one input to an inference process that yields an interpretation of a speaker's meaning. ${ }^{66}$ According to this pragmatic perspective, the simultaneous operation of the two models is necessary because meaning is linguistically underdetermined. Therefore, an addressee must always contextually enrich or adjust ${ }^{67}$ meaning in a variety of ways in order to infer the speaker's meaning. ${ }^{68}$

Take the question: "Can you pass the salt?" Part of the meaning of the linguistic items in the example, such as salt, can be decoded. Whether the interrogative sentence is to be understood as a request or as a question cannot be decoded, but has to be contextually inferred. If we return to our example as to where POWs have to be kept, this means that understanding even the short phrase "on land" will be a product of both decoding and inference. The section on cognitive pragmatics will describe these processes in more detail.

To better understand the difference between decoding and inference, we can also look at the meaning of the word "or." The word appears frequently in international treaty texts. In a nutshell, ${ }^{69}$ semantically ${ }^{70}$ "or" encodes an inclusive reading. Under this reading, "P or Q" means "P or Q or both." This minimal encoded meaning can also be used to convey a pragmatically modified-or, rather, an enriched, more informative exclusive meaning. In this case, "P or Q" would convey "P or Q, but not both." ${ }^{71}$ Without inference, it is impossible to decode "or" in order to ascertain whether a communicator wants to convey an inclusive or an exclusive meaning. Some practical examples may help demonstrate how inference, often drawing from the context, works.

Take the example: "To play Bardot, the actress needs to be sensuous or seductive." Having both qualities would not be a problem here-illustrating an inclusive meaning of "or." In "At the moment, Jack is waiting at the airport or he is flying over the Alps", Jack cannot be in both places-illustrating an exclusive meaning of "or." In "The ideal candidate should have a law degree or a keen awareness of the legal system", both an inclusive and an exclusive reading seems possible. ${ }^{72}$

If we accept this, the same applies to legal norms including “or." Take the example of Article 3 of the European Convention on Human Rights and Fundamental Freedoms: "No one shall be subjected to torture or to inhuman or degrading treatment or punishment."73 A look at the European Court of Human Rights case $\operatorname{law}^{74}$ reveals that there is no uniform interpretation of the three occurrences of "or" in this norm. The Court sometimes uses the terms inhuman and degrading interchangeably; it does the same with the terms treatment and punishment. Certain acts were thus considered to be inhuman, others degrading, and some inhuman and degrading. The Court approached treatment and punishment similarly. In linguistic terms, "or" thus has an inclusive meaning for the Court in these two instances. By contrast, the Court strongly distinguishes between the terms torture and "inhuman or degrading treatment or punishment": Acts can either amount to (1) torture, or (2) to inhuman or degrading treatment

\footnotetext{
${ }^{66}$ JaCQUes Moeschler, Pragmatics, Propositional and Non-Propositional Effects: Can a Theory of Utterance Interpretation Account for Emotions in Verbal Communication?, 48 Soc. SCI. INFO. 452 (2009).

${ }^{67}$ Carston, supra note 64 , at $12-13$.

${ }^{68}$ Wilson, supra note 65 , at 613 .

${ }^{69}$ See Jennifer Smolka \& Benedikt Pirker, International Law, Pragmatics and the Distinction between Conceptual and Procedural Meaning, 7 INT'L J. LANGUAGE \& L. 117 (2018).

${ }^{70}$ For reasons of simplicity, we rely on the account of one particular linguistic theory at this point, namely Relevance Theory - see in more detail subsequent section. This is not to suggest that there are no other linguistic accounts that may be worthy of exploration by international lawyers.

${ }^{71}$ See Coralie Chevallier et al., Making Disjunctions Exclusive, 61 The Q. J. OF Experimental Psychol. 1741 (2008) (arguing that an exclusive reading is compatible with the semantics of "or" in the sense that at least one of the conjoined phrases or sentences is true).

${ }^{72}$ Caterina Mauri \& Johan van der Auwera, Connectives, in CAmbridge Handbook of Pragmatics 388 (Allan Keith \& Katarzyna Jaszczolt eds., 2012).

${ }^{73}$ European Convention on Human Rights, art. 3, June 1, 2010 (emphasis added).

${ }^{74}$ See Schabas, supra note 21, at 174.
} 
or punishment. ${ }^{75}$ But they cannot be both. Consequently, an exclusive reading has been given to the "or" in question. The Court rarely explains this part of its process of reasoning clearly. Nonetheless, it is obvious that the Court is, in practice, drawing inferences to interpret "or", as simply decoding "or" would not yield these results. Based on this simple example, one can already think of many instances of interpretation or treaty-drafting processes where such linguistic knowledge could hone legal-analytical methods.

In linguistics, a number of different views developed as to where the border between decoding and inference falls. Within pragmatics there is yet another distinction whereby some scholars have focused more on so-called conventions of language use and others on so-called intentions. Take Speech Act Theory as an example. In its origins, Speech Act Theory challenges an earlier conception in the philosophy of language where language was thought to have the exclusive purpose of stating or denying truth. ${ }^{76}$ Speech act theory argued that in many ways, saying is doing, often using examples from the law for this purpose. ${ }^{77}$ Think of the language of the civil registry office where the uttering of certain words under certain conditions-"I pronounce you wife and husband"-can result in a fully functional marriage. The speech-act theoretic emphasis on embedding language within human activities is, at the same time, closely related to sociology and its study of language use. ${ }^{78}$ Speech Act Theory thus calls attention to the linguistic creation of social realities, although it pays surprisingly little attention to power relations while doing so. ${ }^{79}$

The study of speech acts has revealed that there is often a significant gap between the meaning encoded in a linguistic form and the interpretation intended by the speaker. While speech acts may go wrong, addressees are typically able to fill this gap in an effortless way. Apparently, there has to be some set of systematic principles that govern linguistic interaction, in the sense that language gained a new dimension when used in interaction. ${ }^{80}$ Accordingly, some have tried to define the rules that have to be followed for this purpose, that is, the so-called felicity conditions or required mental states that speakers are assumed to adopt when performing a speech act. ${ }^{81}$ Going somewhat further, others hold that there has to be a cooperative principle, that is, a certain expectation of how the human mind works when engaged in a common activity. Notably, the meaning of linguistic expressions appears to be highly sensitive to the context and the speaker's intentions, so the addressee's task includes identifying such intentions and computing the effects of the non-linguistic or contextual factors pertaining to the linguistic exchange. ${ }^{82}$ It is not difficult to see how human cognition has increasingly become the focus of this direction in linguistic research. Ultimately, however, many approaches remain focused on conventions, such as the principle of cooperation, for communication to succeed. Such conventions are, in turn, no different from codes in the sense of the previously discussed code model.

\footnotetext{
${ }^{75}$ Or they may remain even below that latter threshold.

${ }^{76}$ Marina Sbisà \& Ken Turner, Introduction, in Pragmatics of SpeEch ACtions 11 (Marina Sbisà \& Ken Turner eds., 2013).

${ }^{77}$ See Iwona Witczak-Plisiecka, Speech Actions in Legal Contexts, in Pragmatics OF SpeEch ACtions 614 (Marina Sbisà \& Ken Turner eds., 2013) (describing the founder of Speech Act Theory Austin as drawing on Hart's reflections on the actional nature of legal language, as well as on earlier work by Jeremy Bentham and the nineteenth-century legal positivist John Austin).

${ }^{78}$ Stephen C. Levinson, Activity Type and Language, in TALK AT WORK-INTERACTION IN InSTITUTIONAL SETTINGS 67 (Paul Drew \& John Heritage eds., 1992) (describing "activity types").

${ }^{79}$ Michiel Leezenberg, Power in Speech Actions, in Pragmatics of SpeEch Actions 294 (Marina Sbisà \& Ken Turner eds., 2013).

${ }^{80}$ John Langshaw Austin, How to Do Things with Words (1962); John Searle, Speech Acts: An Essay IN the Philosophy of Language (1969); Herbert Paul Grice, Logic and Conversation, in Syntacs and Semantics, Vol. 3: Speech Acts (Peter Cole \& Jerry Morgan eds., 1975).

${ }^{81}$ SEARLE, supra note 80 .

${ }^{82}$ Grice, supra note 80 .
} 
From this point onwards, research in pragmatics split into two separate branches. One side, to be discussed in the next section, turned away from conventions and towards a cognitive science approach by starting to focus on the human mind, intentions, and their role in communication. This line of research is often called internalist. ${ }^{83}$ The other, externalist side, continued to pursue non-cognitive pragmatics and, like sociological approaches, was interested in conventions and social and relational features of language. ${ }^{84}$ At a more fundamental level, this divide is reflected in the ongoing debate in pragmatics over whether language is a social or a natural product. $^{85}$

One important example of the externalist approach is discourse analysis. Several approaches can be grouped under this label. ${ }^{86}$ For example, conversation analysis deals with written and/or oral discourse, written and deferred communication being seen as an abstraction from face-to-face communication. ${ }^{87}$ While our international law example is monologic in principle, it could also be seen as part of a dialogical negotiation consisting of proposition, reaction and ratification. ${ }^{88}$ The proposition would be a question asked about Article 22, either by its drafters-"how does Article 22 apply in the given context?"-or a reader-"how do you apply Article 22 in the given context?" The reaction would be Aust's monologic move. The ratification would be the potential reader's reaction-agreement or disagreement. Such an analysis could also focus on the underlying praxeological structure ${ }^{89}$ consisting of scripts or prototypical representations regarding specific roles-e.g., judge and party representative at an international court-and appropriate sequences of events - e.g., opening of the hearings, pleadings by the parties, pronouncement of

\footnotetext{
${ }^{83}$ See Sbisà \& Turner, supra note 76 , at 19

${ }^{84}$ Sbisà \& Turner, supra note 76 , at 19.

${ }^{85}$ AnNe Reboul \& JACQUes MoESCHLER, LA PRAgMATIQUe AUJOURD'HUI: UNE NOUVELle SCIENCE DE LA COMMUNICATION 13-4 (1998). For example, social pragmatics follows the idea that communication involves social conventions and routines and puts the emphasis on external factors such as power relationships among the participants that determine linguistic use (see Victoria Escandell-Vidal, Pragmatics and Cognition, in The Encyclopedia of Applied Linguistics 4 (Carol A. Chapelle ed., 2013)).

${ }^{86}$ Among other discourse analysis approaches that can be used to study law and, in particular, international law, there is, for example, text linguistics, which adopts a discourse-internal perspective and focuses, for instance, on discourse connectives, coherence, well-formedness and elements of textual progression (see Anita Fetzer, The Structuring of Discourse, in Pragmatics of SPeech Actions 685 (Marina Sbisà \& Ken Turner eds., 2013); see also Nicolas Asher \& AleX LASCARIDES, LOGICS OF CONVERSATION (2003)). Our international law example contains complex sentences with dependent clauses connected by adversative conjunctions ("although", "but"). The excerpt is arguably an example of the argumentative text type. Together with other indicators, such as the thematic content and formal organization of the text, which includes complex sentences and formulaic expressions like "... it is not for an international tribunal to ...," the text can be recognized as belonging to the genre of legal academic scholarship (e.g., a textbook or journal article). While some approaches to text linguistics appeal to cognitive categories such as discourse coherence, they do not provide a psychologically plausible model of cognitive processing and do not explain how the cognitive processing of texts actually works (see generally ROBERT DE BeAugrande \& Wolfgang Dressler, Introduction to TeXt Linguistics 102 (1981)). They therefore maintain conventionalist criteria and cannot be called cognitive in the sense of cognitive linguistics or pragmatics. To give another example critical discourse analysis studies larger units of text or discourse to examine how social structure is reflected in discourse (see Siobhan Chapman, Pragmatics 183 (2011); Fetzer, supra note 86, at 685). In our example, the author can be seen as enjoying authority qua publication of his opinion in a reputed medium and qua mastery of legal writing. The author derives power from his elite group membership, which is implicit in his publication. He reproduces the power structure by using a specifically legal style of writing. In our example, two linguistic expressions contrast with the rather neutral wording of the text through their strong evaluative connotation: "Good" and "common sense." By using these positively connoted expressions, the author elevates his own opinion to make it more powerful. This exercise of power is supported by the context of the author's publication (scholarly monograph), which implies that the author is an expert in his field.

${ }^{87}$ JACQUes MOESCHLER \& ANTOINe AUChlin, INTRODUCTION À LA LINGUisTiQUe CONTEMPORAine 194 (2009); see also Laurent Filliettaz \& Eddy Roulet, The Geneva Model of Discourse Analysis: An Interactionist and Modular Approach to Discourse Organization, 4 Discourse STUD. 370 (2002) (providing an interactionist and modular alternative to the classic turn-taking system in conversation analysis).

${ }^{88}$ Eddy Roulet, Laurent Filliettaz \& ANNE Grobet, Un MOdèle ET Un INSTRUMENT D'ANALYSE DE L'ORGANISATION DU DISCOURS 57 (2001).

${ }^{89} \mathrm{Id}$. at 213.
} 
judgment, etc. ${ }^{90}$ With regard to domestic law, some law and language scholars have developed comparable approaches. ${ }^{91}$

In summary, the non-cognitive approaches mentioned can benefit the study of international law. Yet, to gain more thorough insights into the operation of language in the human mind, we suggest turning to internalist approaches. The latter cast doubt on the tendencies that perceive language as a given code observed in sociological and cognitive sociological approaches to international law.

\section{Cognitive Linguistics: The Case of Cognitive Pragmatics}

As discussed in the last section, some speech act philosophers followed the general cognitive trend at the end of the 1970s and shifted their attention away from speech as action and social interaction to the mind, mental attitudes and intentionality. ${ }^{92}$ One of the core theories that emerged from this development is Relevance Theory. If one imagines this development of different lines of research as a spectrum, Relevance Theory is situated at the very intentional end as opposed to the conventional end of the spectrum. It replaces conventional maxims of conversational cooperation with the cognitive principle of relevance and emphasizes inferential processes over social rules in verbal communication. ${ }^{93}$

According to Relevance Theory, communication is a two-fold intentional process: It is ostensive in the sense that a communicator must explicitly or overtly show a communicative intGention - ostension - to communicate a piece of information to the addressee. The addressee then has to infer the piece of information-inference. ${ }^{94}$ Human cognition is entirely constrained by the principle of relevance, that is the aim to maximize relevance. ${ }^{95}$ Despite its vagueness, more or less implicit verbal as well as non-verbal communication is mostly successful because a communicator's informative intention is merely to modify the cognitive environment of the audience, not their thoughts directly. ${ }^{96}$ In other words, there are no thoughts "travelling" from one brain to another, ${ }^{97}$ but merely cognitive environments - that is sets of assumptions that are manifest to an individual-which the individual entertains as true or inferable in the inferential process of verbal communication..$^{98}$ An interpretive process strengthens, weakens, or suppresses old assumptions and generates new ones. ${ }^{99}$ The more similar assumptions people share, the greater the overlap between their cognitive environments, and the more likely the search for relevance will lead to successful communication. ${ }^{100}$ In practice, the principle of relevance operates on a cost-benefit basis, weighing up processing effort as costs and cognitive effects as benefits. ${ }^{101}$ A somewhat simplified description of the comprehension procedure would be as follows: First follow a path of least effort in computing cognitive effects-e.g., testing various interpretive hypotheses-and then stop when your expectations of relevance are satisfied. ${ }^{102}$ This also seems to mirror other cost-benefit operations in the human mind that cognitive sociology relies on. ${ }^{103}$

\footnotetext{
${ }^{90}$ Filliettaz \& Roulet, supra note 87 , at $381-82$.

${ }^{91}$ See Structuring Legal Theory, Friedrich Müller, Strukturierende RechtSlehre (1994); Hanjo Hamann, Strukturierende Rechtslehre als juristische Sprachtheorie, in HANDBUCH SPRACHE IM RECHT (Ekkehard Felder \& Friedemann Vogel eds., 2017).

${ }^{92}$ Sbisà \& Turner, supra note 76 , at 3.

${ }^{93} I d$. at 10 .

${ }^{94}$ Reboul \& MOESChler, supra note 85 , at 72; Zufferey \& MOESChler, supra note 65, at 108.

${ }^{95}$ DAN SPERbER \& DeIrdRe Wilson, ReleVANCE. COMMUNICATION AND COGNITION 261 (1995); Carston, supra note 64, at 28.

${ }^{96}$ SPERBER \& Wilson, supra note 95 , at 58.

${ }^{97} I d$. at 1 .

${ }^{98}$ Moeschler, supra note 66 , at 456.

${ }^{99} I d$. at 456 .

${ }^{100}$ SPERBER \& WiLSON, supra note 95 , at $41,44$.

${ }^{101}$ Deirdre Wilson, Relevance Theory and Lexical Pragmatics, 15 Italian J. Linguistics 282 (2003).

${ }^{102}$ See Carston, supra note 64, at 28.

${ }^{103}$ See supra Section C.II.
} 
Relevance Theory also casts doubt on linguistic approaches that are based on conventions to explain language use. As discussed above, such approaches rely on principles agreed upon among participants in communication so that the latter can succeed. Relevance Theory proceeds differently. The mutual knowledge requirement presents a core problem for conventionalist theoriesincluding much of the sociological work mentioned in section C.IV - that see language as a readyto-use code determined by social practice. From an exclusively conventionalist perspective a communicator and an addressee would have to know that only shared assumptions-e.g., the cooperative principle - are used in a communication process. For this purpose, however, the addressee would have to know that the communicator holds an assumption, which again the communicator would have to know, and so forth ad infinitum. ${ }^{104}$ Instead of this mutual knowledge requirement, Relevance Theory bases itself on the Theory of Mind to explain how addressees can achieve a correct interpretation in a process of communication. According to this account, communicators and addressees are mind-readers. ${ }^{105}$ Humans have an innate ability to attribute mental states, such as intentions or beliefs, to others. This is called the intentional stance. ${ }^{106}$ The reliance on such innate abilities is a parallel of this approach to cognitive sociology. Although not infallible, ${ }^{107}$ the intentional stance allows an individual to explain and predict the behavior of others and to manipulate their mental states, starting from the premise that other individuals are rational agents and endowed with beliefs, desires, and other mental states. ${ }^{108}$ This means that for the purposes of communication, there is no need for the mentioned mutual knowledge requirement. It suffices that there is mutual manifestness. Mutual manifestness means that an individual may base themselves on the intentional stance to attribute a similar manifestness to their interlocutor. ${ }^{109}$ Think at this point of our previous example of: "Can you pass the salt?" There is, in a relevance-theoretic account, no need for overarching principles that an addressee and a communicator need to know mutually, for example the precise contexts in which the example is to be understood as a request or as a question about the ability to pass the salt. It suffices that the addressee proceeds according to the principle of relevance to go on interpreting until a hypothesis-for instance that the communicator aims to communicate a request-fulfils their expectations of relevance, for example based on the context that both participants are sitting at a dinner table with the salt shaker in front of the addressee.

An example from a context closer to international law elucidates inference and also the difficulties of an externalist account based on conventions, as well as the relevance-theoretic comprehension procedure. ${ }^{110}$ Imagine a written international law exam given at a Swiss university in which the students receive the following question: "How does one determine which State is authorized to exercise diplomatic protection for a particular legal person?" The question addresses a classic topic of international law, and the examiner would expect an answer to be aware of the various theories that exist to prove a link between a legal person and a State, to comment on the relevant case law of the International Court of Justice ${ }^{111}$ and, ideally, to express the candidate's own views on the topic. Out of a group of about 100 students taking the exam, most provided a reply more or less along these lines, differing of course with regard to their level of knowledge and grasp of the subject. By contrast, one student explicated the various theories, but then very

\footnotetext{
${ }^{104}$ SPERBER \& Wilson, supra note 95, at 17.

${ }^{105}$ Moeschler, supra note 66, at 453.

${ }^{106}$ Jacques Moeschler, Is Pragmatics of Discourse Possible, in Perspectives on Language, Use and Pragmatics. A Volume in Memory of Sorin Stati 223 (Alessandro Capone ed., 2010) (citing Daniel Dennett,The Intentional STANCE (1987)).

${ }^{107}$ Anne Reboul \& Jacques Moeschler, Pragmatique du discours. De l'interprétation de l'énoncé À L'INTERPRÉTATION DU DISCOURS 48 (1998).

${ }^{108}$ Wilson \& Sperber, supra note 65 , at 610 \& 623; RebOul \& MOESCHLER, supra note 85 , at 47.

${ }^{109}$ SPERBER \& Wilson, supra note 95, at 41.

${ }^{110}$ See Pirker \& Smolka, supra note 5, at 259 (discussing the example in a slightly different context).

${ }^{111}$ Barcelona Traction, Light \&amp; Power Co. (Belgium vs. Spain) Judgment 1970 I.C.J. 3, 42 (Feb. 5).
} 
briefly_and correctly ${ }^{112}$ — concluded: "But in Switzerland, the control theory is the predominant and thus applicable theory."

This example explores two elements. First, it is again a good example of inference. One student read the exact same question as their peers, but understood it with an additional element: Namely, the student inferred that they were answering this question in an international law exam at a Swiss university. They therefore read the question as including "in Switzerland," and the question was about identifying the relevant state of the law in Switzerland. No explicit element of the text on the exam paper leads to this conclusion-nor did it for the 99 other students.

Second, it shows a process of interpretation in which Relevance Theory provides a more helpful account than thinking in terms of conventions and mutual knowledge requirements-i.e. an externalist account. In cases where the exam question is not phrased with perfect clarity, we might think that there is some sort of convention that guides the students' comprehension process. The convention would thus be something along the lines of: "If you are asked exam question X, you are supposed to answer it at the level of general international law, not at the level of one specific national legal order." Even if it does not appear very realistic, we can assume that there was a convention that the professor-as the drafter of the exam-knew, that the students knew that the professor knew, that the professor knew that the students knew the professor knew, and so on and so forth. The convention failed in the case of one student. Does this mean that there is no convention? Or does it mean that the student was the one person not participating in the convention and/or was unaware of the mutual knowledge on which this particular process of communication was based? What we know for certain is that communication did not break down entirely, even for this one student. The student reached an understanding of the exam question. Was there a separate convention at work?

Consider, by contrast, the account offered by Relevance Theory. The latter would simply suggest that 99 students followed the path of least effort in computing cognitive effects and stopped when they found their expectations of relevance satisfied. For them, the question asked about the state of the law in international law. This was the most relevant interpretive hypothesis to their situation. For one student, however, the contextual element of writing an exam in Switzerland at a Swiss university was an element to be taken into account that led him or her to be satisfied with a different interpretive hypothesis, namely that the question was about the legal situation in Switzerland. This appears to be a quite tenable explanatory model for the results of the communication process. Such a refined understanding of the cognitive processes of language comprehension could also help us predict interpretations better-and aid in international treaty drafting.

At this point, it should be noted that the focus of cognitive pragmatics in the form of Relevance Theory significantly differs from that of cognitive sociology. As described in Section C.II., cognitive sociology aims to identify what is conventional in the black box of mental processing. It stays away from purely subjective factors, focusing on the inter-subjective social world and analyzing human cognitive diversity and differences as part of different thought communities. By contrast, cognitive pragmatics takes an individual and psychological perspective. ${ }^{113}$ Relevance Theory is, in this regard, reductionist, as it considers conventions of language use to be sociological or legal questions rather than issues of pragmatics. ${ }^{114}$ Pragmatics as a whole is seen as a capacity of the mind. ${ }^{115}$ This difference does not, however, entail the view that cognitive pragmatics and cognitive sociology are mutually exclusive or in conflict. It is a mere difference of perspective. With regard to commu-

\footnotetext{
${ }^{112}$ Note de la Direction du droit international public of 20 August 2002, addressed to the Political Division II of the Département fédéral des affaires étrangères, 13 Revue SuISSE DE Droit INTERNATIONAL et EuropéEn 454-55 (2003).

${ }^{113}$ Susan Foster-Cohen, Relevance Theory, Action Theory and Second Language Communication Strategies, 20 SECOND Language Res. 294 (2004); Diane Blakemore, Understanding Utterances: Introduction to Pragmatics 4 (1992).

${ }^{114}$ Reboul \& MOESCHLER, supra note 85, at 172.

${ }^{115}$ Robyn Carston, Thoughts and UtTERANCES 128-29 (2002).
} 
nication, cognitive sociology is more interested in how patterns of underlying mental activity pertain to the dynamics of social interaction. Cognitive pragmatics is more interested in characterizing the mental processes by which an addressee discovers what is being communicated, ${ }^{116}$ abstracting in a way from social conventions or rules in social interaction. ${ }^{117}$ Both disciplines can benefit from one another. Cognitive sociology, which sees language as inseparable from social practice, would benefit from a greater awareness of how language works, especially regarding the linguistic underdeterminacy of words and utterances and how this affects the black box of mental processing. ${ }^{118}$ According to Relevance Theory, social practice is one contextual element among others in the cognitive environment that may form part of the cognitive cost-benefit analysis of relevance. ${ }^{119}$ Yet, the theory includes such information without formal analysis. Cognitive sociology may help to model and formalize the cost-benefit analysis. ${ }^{120}$

In summary, Relevance Theory is a major theory in pragmatics that emerged as part of the cognitive turn in linguistics and, in particular, pragmatics. It explains communication through the operation of the human mind, using concepts like the principle of relevance and the intentional stance. It remains, however, to be shown how the theory can be made useful for international law.

\section{Cognitive Pragmatics and International Law}

At this point, we will focus on how cognitive pragmatics can be of help in studying the previous example of a process of interpretation in international law. ${ }^{121}$ Remember that Aust states that Article 22, "clearly prohibits holding on ships POWs who are captured on land." Using pragmatics, an interpreter could infer from Aust's utterance that this prohibition does not apply to persons captured at sea. According to Relevance Theory, this would be a so-called implicature, which means the - defeasible ${ }^{122}$ - inference is not drawn from the explicit content.

To interpret the utterance, an addressee also needs to use inferences at the explicit level, socalled explicatures, that is the explicit content of the linguistic evidence provided. ${ }^{123}$ Take the example of the term land. Aust's reasoning and the related interpretive process can arguably be presented in more transparent terms using pragmatics, namely as a process of broadening or loosening the linguistic content encoded in the term land. ${ }^{124}$ There is, therefore, decoding and inference at play, as in the previous example of "can you pass the salt?" The concept of land

\footnotetext{
${ }^{116}$ BLAKEMORE, supra note 113 , at 3-4.

${ }^{117}$ Abstraction should be understood as an absolute term in this context. Relevance Theory simply treats social information the same way as other information, meaning such information is noticed and stored, and over time individuals come to recognize features of social class, ethnic identity, power, solidarity, politeness, etc. in other individuals through their communicative behavior. As such information is accessible like anything else; there is no need to separate out the tasks of computing the communicative function of an utterance, of incorporating socio-cultural knowledge and of determining inferences, as these tasks are all accomplished simultaneously by the human information processing system in the act of comprehension based on the principle of relevance (see Foster-Cohen, supra note 113, at 294, 300).

${ }^{118}$ Witczak-Plisiecka, supra note 77, at 643.

${ }^{119}$ Smolka \& Pirker, supra note 63, at 19.

${ }^{120}$ See ASHER \& LASCARIDES, supra note 86, at 442-43.

${ }^{121}$ See Pirker \& Smolka, supra note 5, at 30-35 (engaging in more detail with the example).

${ }^{122}$ At the same time, the example shows that inferences are defeasible. Aust does not intend to convey that the clear prohibition does not apply to persons captured at sea but that the relevant prohibition is less clear with regard to such persons. Only this most recent commentary on the relevant norms suggests a clarification: according to the second sentence of Article 16 of the Second Geneva Convention read in conjunction with Article 22 of the Third Geneva Convention, "persons may only be held on board a ship as a temporary measure, pending transfer to land" (see Convention (II) for the Amelioration of the Condition of Wounded, Sick and Shipwrecked Members of Armed Forces at Sea, Geneva (Aug. 12, 1949) Commentary of 2017, Article 16: Status of the Wounded, Sick and Shipwrecked Who Have Fallen Into Enemy Hands, 1579).

${ }^{123}$ Kristin Börjesson, The Semantics-Pragmatics Controversy 114 (2014).

${ }^{124}$ Carston, supra note 64, at 12 (noting that cases of broadening appear to be less widely agreed on than those of narrowing).
} 
encodes a certain semantic - that is, decodable-meaning. For example, the assumption that land is firm ground that may border on water but is different from it. Semantic meaning, however, is generally underdetermined. ${ }^{125}$ The decoded meaning of land must thus be pragmatically, that is inferentially-i.e., through inference-enriched in interpretation, resulting in a so-called ad hoc concept. ${ }^{126}$ In the formation of such a concept, the semantic content of a given lexical item such as land is pragmatically adjusted based on the principle of relevance to express conceptual content that may be narrower or looser than the decoded meaning. ${ }^{127}$ This is, however, not to be confused with any non-literal use. ${ }^{128}$

In our example, nonetheless, the effect can be remarkable. Aust can thus be said to modulate the linguistic content of the term land based on context. In Article 22, the obligation to intern POWs "only in premises located on land" is followed by another condition, namely "and affording every guarantee of hygiene and healthfulness." What Aust appears to be doing at this point - what he calls reading an implied term into the norm-is to develop the notion of land so as to include the second condition: Land is thus only land if it guarantees certain conditions, here mainly with regard to protection from the elements. He thus narrows the conceptual meaning of the term land in this context. Aust then proceeds to loosen the previously narrowed explicit content. He relies on the fact that accommodation and protection from the elements can also be provided on ships: The conceptual, that is encoded, content of the term ship makes available sufficiently similar information to the narrowed ad hoc concept of the term land, such as firm ground. The linguistic content of the term land is loosened to include "land which can be viewed as adjacent or even contiguous, even if this land is technically located on top of water." Because of Aust's loosening-following the initial narrowing - of the linguistic content of the term land, the ad hoc term no longer applies to land which lacks accommodation, making the holding of POWs on ships_the only remaining option_compliant with the norm.

From a dogmatic point of view on international law, one may legitimately disagree over the persuasiveness of Aust's suggestion. Some may find it to be an adequately pragmatic approach to treaty interpretation, whereas others may object and point out that under the general rules of treaty interpretation they would favor another solution. The point of a cognitive pragmatic analysis - such as that presented by Relevance Theory-is not to address such dogmatic concerns on dogmatic grounds. In contrast to the mentioned ideological approaches of the sociology of international law, Relevance Theory is purely descriptive. Its aim is to show what happens in the interpreter's mind when processing language, which in turn may serve to refine the discussion on interpretation in international law and to help in cases of disagreement on linguistic issues. It offers its own criteria for evaluating a process of interpretation, in particular the cognitive effort involved in determining a given interpretation, which can be of help when international lawyers are confronted with problems within their own system of norms, for example determining the ordinary meaning of a treaty term. ${ }^{129}$

\section{E. Conclusion}

At this point, the question remains whether these cognitive approaches to international law are beneficial. The fact that we have reached a deeper understanding of one central example, as well as the other examples discussed in the Article, indicates that there is a benefit.

Cognitive sociology explains how lawyers may develop prototypes and ideals of concepts through their cognitive socialization, which may then guide their decision-making and judgment. Holding POWs on ships may thus correspond more closely to the prototype than holding them on

\footnotetext{
${ }^{125} \mathrm{Id}$. at $1-2$.

${ }^{126}$ See Wilson \& Sperber, supra note 65 , at 618 (noting the factors affecting this process of enrichment).

${ }^{127}$ BÖRJESSON, supra note 123 , at $117-18$.

${ }^{128}$ Carston, supra note 64 , at 11-12.

${ }^{129}$ Pirker \& Smolka, supra note 5, at 266.
} 
land, as the norm literally prescribes, because of other factors such as the difference in protection from bad weather conditions. Cognitive linguistics - or, more precisely, pragmatics - can help us understand in more detail how language processing works and thus tell us in detail how an interpreting agent in international law can get from holding POWs on land to holding them on ships in precise linguistic terms using concepts such as linguistic underdeterminacy, ad hoc concepts, and explicatures. The approaches discussed are fundamentally descriptive. There is, however, hardly any doubt that a deeper understanding of international law's processes can only be beneficial for its success as a regulatory framework in the long term.

With regard to their relationship to one another, cognitive approaches such as those discussed above may have different emphases, but they are not mutually exclusive or contradictory. The parable of the blind men describing an elephant comes to mind. Cognitive sociology may study thought communities while cognitive pragmatics adopts a more individualist, psychological perspective. As we have demonstrated, however, both can aid a study of international law in their own way.

In conclusion, it may be an overstatement to suggest that the very future of international law is cognitive. ${ }^{130}$ Still, we believe that cognitive approaches need to be part of international law's future. There is, therefore, value in acquiring knowledge of these methods and reflecting on how to usefully apply them to the study of international law in the future.

\footnotetext{
${ }^{130}$ The present Article's title is inspired by a seminal article from a different context (see ANNE-MARIE SLAUGHTER \& William Burke-White, The Future of International Law is Domestic (or, The European Way of Law), 47 HARV. INT'L L. J. 327 (2006).
}

Cite this article: Pirker B, Smolka J (2019). The Future of International Law is Cognitive-International Law, Cognitive Sociology and Cognitive Pragmatics. German Law Journal 20, 430-448. https://doi.org/10.1017/glj.2019.30 